Terakreditasi Sinta 3 | Volume 3 | Nomor 2 | Tahun 2020 | Halaman 125-138

P-ISSN 2615-725X | E-ISSN 2615-8655

http://diglosiaunmul.com/index.php/diglosia/article/view/34

\title{
BENTUK-BENTUK PENYIMPANGAN DALAM NOVEL KIAT SUKSES HANCUR LEBUR KARYA MARTIN SURYAJAYA: KAJIAN STILISTIKA
}

\section{The Deviations in "Kiat Sukses Hancur Lebur" Novel by Martin Suryajaya: A Stylistic Analysis}

\author{
Norma Atika Sari \\ Program Studi Sastra Indonesia, \\ Fakultas Ilmu Budaya, Universitas Mulawarman \\ Pos-el korespondensi: atikasari.norma@gmail.com
}

\begin{abstract}
This study focused on the analysis of irregularities featured form in the novel Kiat Sukses Hancur Lebur by Martin Suryajaya. The research variables were forms of lexical, grammatical, paragraph, discourse, plot, and forms of narrative delivery. This research was a qualitative descriptive study and data collection was conducted by reading and note taking techniques. The results found that many deviations such as selection of odd words, the formation of incoherent sentences and paragraphs, the discourse that presents a critique of capitalism and postmodernism through symbols, as well as the emergence of unusual forms of novel structures namely footnotes, charts, diagrams, schematics, paintings, drawings, line types, pictures, photographs, tables, balance sheets, formulas, maps and bibliography. These deviations show the author's unique style and novelty in the form of aesthetic absurdity in the treasury of contemporary Indonesian literature.
\end{abstract}

Keywords: style, stylistics, deviations, aesthetics, absurdity

\begin{abstract}
Abstrak: Penelitian ini memfokuskan diri pada analisis bentuk-bentuk penyimpangan yang ditampilkan dalam novel Kiat Sukses Hancur Lebur karya Martin Suryajaya. Variabel penelitian ini adalah bentuk-bentuk penyimpangan leksikal, gramatikal, paragraf, wacana, alur serta bentuk penyampaian narasi. Penelitian ini adalah penelitian deskriptif kualitatif dan pengumpulan data dilakukan dengan teknik baca dan catat. Hasil penelitian menemukan banyak penyimpangan dari mulai pemilihan kata yang janggal, penyusunan kalimat serta paragraf yang tidak koheren, diskursus yang menampilkan kritik terhadap kapitalisme dan postmodernisme melalui simbol-simbol, serta munculnya bentuk-bentuk struktur novel yang tidak wajar yaitu catatan kaki, bagan, diagram, skema, lukisan, gambar, jenis garis, gambar, foto, tabel, neraca, rumus, peta dan daftar pustaka. Penyimpangan-penyimpangan ini menampilkan stile khas pengarang dan kebaruan bentuk berupa estetika absurditas pada khazanah kesusastraan Indonesia mutakhir.
\end{abstract}

Kata kunci: stile, stilistika, penyimpangan, estetika, absurd

\section{A. PENDAHULUAN}

Karya sastra menangkap realitas kehidupan, mengolah bahan tersebut, kemudian merepresentasikannya kembali ke dalam bentuk yang baru. Bentuk yang dihasilkan dapat berupa imitasi kehidupan/mimesis, atau sebaliknya melalui penyimpangan-penyimpangan dan penundaan makna. Cara seorang sastrawan merepresentasikan kembali realitas membentuk gaya khas yang melahirkan ciri kepenulisan seorang sastrawan yang membedakannya dengan sastrawan lain. Gaya khas ini dapat diidentifikasi oleh pembaca. Dalam sirkuit bisnis, pembaca pada akhirnya bebas memilih membaca genre karya sastra sesuai selera dan minatnya. Gaya khas ini juga sangat beragam sehingga memperkaya keberagaman bentuk pada khazanah kesusastraan Indonesia.

Gaya atau stile khas seorang sastrawan berangkat dari pandangan estetis yang dianutnya. Motif penciptaan 
sebuah karya sastra juga bertolak dari pandangan estetis ini. Horace secara dikotomi membagi konsep estetika menjadi dulce dan utile (indah dan berguna). Teeuw menyebut bahwa tugas seniman menurut Horace bukan hanya sebatas memberi ajaran dan menampilkan keindahan, namun juga imovere, yaitu menggerakkan pembaca ke kegiatan yang bertanggungjawab (Teeuw, 1984, hal. 51). Berangkat dari pemikiran ini, karya sastra adalah sebuah struktur yang kompleks. Sebuah karya sastra tersusun dari struktur dan teks yang secara konvensi harus indah, berguna, atau mampu memberikan efek didaktis kepada pembaca.

Aspek keindahan dalam karya seni melahirkan aliran estetika yang beragam, di antaranya aliran romantik, impresionisme, ekspresionisme, simbolisme, jugendstil, fauvisme, surealisme, kubisme, seni abstrak dan lain sebagainya. Ada kalanya menilai karya seni dari aspek keindahan bertentangan dengan menilai bobot fungsi dan peran karya sastra untuk menginisiasi pergerakan. Dari pertentangan ini, karya sastra seolah selalu berada di antara dua kutub: indah, berguna, atau keduaduanya.

Novel berjudul Kiat Sukses Hancur Lebur (2016) karya Martin Suryajaya hadir merombak konsep ideal Horace terhadap karya seni, yaitu dulce et utile (indah dan berguna). Novel ini seolah mencoba mendefinisikan ulang pengertian "indah" dan hampir mustahil untuk menemukan apa fungsi dan beban pesan yang ingin disampaikan ke pembaca tanpa mengalami fase kebingungan menafsirkan teks apa yang sebetulnya ingin disampaikan oleh pengarang. Novel ini diterbitkan oleh Penerbit Banana tahun 2016 dan merupakan novel pertama karya Martin Suryajaya yang berprofesi sebagai editor jurnal IndoProgress. Sebelumnya, Martin sudah menerbitkan beberapa buku ilmiah, yaitu Materialisme Dialektis (2012), Asal-Usul Kekayaan (2013) dan
Sejarah Estetika (2016). Secara sepintas, susunan novel ini terlihat seperti susunan buku ilmiah, yakni terdiri atas bagian Catatan Editor, Bab I s.d. Bab VIII, serta ditutup dengan Daftar Pustaka. Secara umum struktur bentuk novel ini amburadul sesuai dengan judulnya: Kiat Sukses Hancur Lebur. Menariknya, novel ini bukan hanya berisi narasi cerita, namun juga berisi gambar, daftar, tabel, diagram, lukisan, bagan, neraca, foto, rumus-rumus, bahkan daftar pustaka yang semuanya fiksional.

Ketidakwajaran bentuk dan temuan awal banyaknya penyimpanganpenyimpangan adalah alasan mendasar dipilihnya novel ini sebagai objek penelitian. Pesan yang sulit ditangkap karena banyaknya deviasi serta bentuk yang jauh dari konvensi keindahan menjadikan novel ini unik dan menarik. Berdasarkan latar belakang tersebut, tujuan umum penelitian ini adalah menganalisis bentuk-bentuk penyimpangan dalam novel Kiat Sukses Hancur Lebur serta stile khas Martin Suryajaya. Sedangkan tujuan khusus penelitian ini adalah (1) mengungkap bentuk penyimpangan-penyimpangan dalam novel Kiat Sukses Hancur Lebur karya Martin Suryajaya, serta (2) hubungan penyimpangan-penyimpangan tersebut dengan pembentukan stile khas dan estetika kepengarangan Martin Suryajaya. Untuk mencapai dua tujuan tersebut, dalam penelitian ini digunakan teori stilistika teori Pascastrukturalisme.

Teori stilistika dapat dimanfaatkan sebagai pendekatan yang efektif untuk menganalisis gaya bahasa pada sebuah teks baik dalam ruang lingkup linguistik maupun sastra. Ratna menyebutkan stilistika (stylistics) adalah ilmu tentang gaya, sedangkan stile (style) secara umum adalah cara-cara khas bagaimana sesuatu diungkapkan dengan cara tertentu sehingga tujuan yang dimaksudkan dapat dicapai secara maksimal (Ratna, 2009, hal. 3). Hubungan sastra dan stilistika terlihat 
lebih jelas dari penjelasan Leech \& Short yang menyebutkan bahwa sastra adalah studi tentang stile, yaitu kajian terhadap wujud formasi kebahasaan, khususnya yang terdapat dalam teks kesastraan (Nurgiyantoro, 2014, hal. 75).

Berbeda dengan kajian linguistik, penelitian dengan pendekatan stilistika dalam ranah sastra bukan hanya bertujuan menganalisis gaya atau stile saja, namun tujuan akhirnya adalah menemukan bagaimana stile tersebut membentuk gaya khas seorang sastrawan yang membentuk ciri estetik yang membedakannya dengan sastrawan lain. Wellek \& Warren (2016, hal. 206) menyatakan bahwa manfaat penelitian stilistika yang sepenuhnya estetis membatasi lingkup bidang ini khusus untuk studi karya sastra dan kelompok karya yang dapat diuraikan fungsi dan makna estetisnya. Baru jika tujuan estetis ini menjadi inti permasalahan, stilistika merupakan bagian ilmu sastra. Hanya metode stilistikalah yang dapat menjabarkan ciri-ciri khusus karya sastra.

Stilistika dapat diimplementasikan untuk penelitian terhadap seluruh genre karya sastra baik puisi, fiksi maupun naskah drama. Dalam analisis karya fiksi, penelitian stilistika memfokuskan diri pada analisis terhadap aspek struktur dan bentuk. Nurgiyantoro (2014, hal. 249) menyebutkan bahwa aspek stile juga memegang peranan penting dalam karya fiksi karena semua hal yang dikisahkan menggunakan sarana bahasa. Namun jika dilihat dari fungsi keindahan yang ingin dicapai, bahasa tidak menjadi satusatunya unsur analisis seperti dalam teks puisi. Dalam fiksi, faktor kehebatan cerita, jalinan konflik yang kompleks, penyiasatan peristiwa lewat alur, kekhasan tokoh, dan kebaruan tema juga menjadi bahan kajian yang penting.

Ratna menyebutkan bahwa dalam penelitian stilistika karya fiksi, unsur struktur yang menjadi tujuan utama penelitian adalah plot atau alur. Plot membawa ide, pesan, tema, dan pandangan dunia. Kualitas estetis dalam novel juga dapat disimpulkan dari bagaimana peristiwa dan kejadian disusun sedemikian rupa hingga masalah yang biasa jadi luar biasa. Tujuan gaya penyampaian peristiwa ini menjadikan setiap kejadian seolah-olah didengar untuk pertama kali oleh pembaca (Ratna, 2009, hal. 61). Meskipun demikian, bukan hanya unsur alur yang dapat dikaji. Penelitian stile juga dapat dilakukan untuk meneliti unsur struktur lain yaitu tema, tokoh, dan latar. Selain unsur struktur fiksi, penelitian stilistika karya fiksi juga dapat mengkaji aspek leksikal, gramatikal, serta wacana atau diskursus yang termuat dalam teks.

Lebih jauh, hasil kajian stilistika dapat digunakan untuk menyimpulkan gaya atau stile karya fiksi yang bergenre sama. Wellek \& Warren (2016, hal. 213) menyebutkan bahwa dengan menguraikan gaya suatu pengarang, dapat diuraikan juga gaya sekelompok karya, dan genre, misal novel gotik. Ratna (2009, hal. 60) juga mempertegas pendapat ini. Dia menyebutkan bahwa dalam ruang lingkup yang lebih luas, gaya juga dibicarakan dalam kaitannya dengan periode sejarah kesusastraan Indonesia yang membagi periode kesusastraan modern menjadi: gaya Minangkabau pada novel-novel terbitan Balai Pustaka, gaya nasionalisme pada novel-novel terbitan Pujangga Baru, gaya revolusi pada Angkatan '45, gaya penulis perempuan periode 70 -an, dan lain sebagainya.

Dalam penelitian ini, aspek yang secara spesifik akan diteliti adalah bentukbentuk penyimpangan atau deviasi. Keindahan sebuah karya sastra tidak jarang justru diperoleh dari bentukbentuk penyimpangan di dalamnya.

Nurgiyantoro (2014, hal. 289-290) mengemukakan bahwa dalam konteks karya sastra, penggunaan istilah deviasi (deviation) disejajarkan dengan istilah penyimpangan. Deviasi adalah suatu hal 
yang banyak dijumpai dalam berbagai literatur. Leech (dalam Nurgiyantoro, 2014) menyebutkan deviasi berdampak pada psikologis pembaca: pembaca lebih fokus pada sesuatu yang menyimpang. Manipulasi dalam bentuk penyimpangan menarik perhatian pembaca. Semakin aneh bentuk penyimpangan yang ditampilkan, pembaca akan semakin tertarik untuk membaca dan memperbincangkannya.

Aspek penyimpangan dalam karya fiksi dapat ditemukan dalam unsur stile dan unsur struktur khas yang ditampilkan. Dalam level leksikal, Nurgiyantoro (2014, hal. 181) menyebutkan analisis dapat difokuskan untuk menemukan penggunaan kata yang menyimpang, kata kolokial, kata dari bahasa lain, kata yang menunjuk makna khusus, atau repetisi. Semi (2008, hal. 93-137) menyebutkan unsur lain yang dapat dianalisis yaitu gaya penceritaan, gaya pelukisan (deskripsi), pemunculan ragam lokal dalam menghidupkan gaya bertutur, serta pemanfaatan bahasa dalam menciptakan gaya. Manipulasi bahasa dalam karya fiksi dapat dikategorikan menjadi tigas jenis, yaitu (1) berpusat pada kata, (2) berpusat pada kalimat, dan (3) berpusat pada wacana.

Selanjutnya, Semi (2008, hal. 93137) menyebutkan beberapa hal yang dapat diteliti dari gaya yang berpusat pada manipulasi struktur kalimat adalah adanya kalimat bervariasi, pola paralelisme, antitesis, repetisi, klimaks dan anti klimaks, aposisi, dan lain sebagainya. Sedangkan gaya yang berpusat pada wacana (discourse) mengharuskan peneliti melihat sastra sebagai sebuah kesatuan unsur intrinsik dan ekstrinsik yang memiliki gaya yang khas dan spesifik yang dipilih oleh pengarang.

Bentuk-bentuk penyimpangan yang disebutkan di atas akan digunakan sebagai variabel analisis dalam penelitian ini. Namun tidak seluruh unsur penyimpangan yang disebutkan di atas akan diteliti. Aspek penyimpangan yang akan dianalisis dalam penelitian ini adalah (a) penyimpangan leksikal, gramatikal, dan paragraf; (b) penyimpangan wacana; (c) penyimpangan alur cerita; dan (d) penyimpangan struktur. Bentuk-bentuk penyimpangan tersebut akan membentuk gaya atau stile khas pengarang yang membedakannya dengan pengarang lain.

Seperti telah disebutkan sebelumnya, langkah kerja penelitian stilistika dalam perspektif sastra tidak hanya berhenti pada analisis gaya atau stile, namun diteruskan dengan menyimpulkan bentuk stile dominan yang membentuk estetika kepengarangan yang khas. Korelasi antara estetika dan stilistika dijelaskan secara eksplisit oleh Ratna, yaitu stilistika dan estetika bekerja saling meliputi. Stilistika mengimplikasikan keindahan, demikian juga sebaliknya keindahan melibatkan sarana yang dimiliki oleh gaya atau stile yang pada akhirnya mampu mengevokasi unsur-unsur keindahan tertentu. Gaya dan keindahan adalah dua unsur yang saling meliputi dan melengkapi dalam rangka menampilkan makna suatu aktivitas kultural (Ratna, 2009, hal. 253254). Keindahan tidak hanya dapat dicapai melalui keteraturan dan ketaatan, namun tidak jarang justru dicapai melalui ketidakteraturan dan penyimpanganpenyimpangan.

Penyimpangan yang terjadi pada karya sastra menandakan bahwa karya sastra tersebut ingin lepas dari struktur yang sudah ada sebelumnya. Kemapanan struktur melahirkan konvensi dan rasa aman khususnya pada ruang lingkup kesusastraan. Pada karya fiksi, katakanlah novel, struktur terbangun dari tokoh, alur, latar, sudut pandang, dan gaya penceritaan yang dapat diterima secara logis oleh pembaca. Di lain sisi, seperti disebutkan di bagian pendahuluan, bahwa idealnya sebuah karya sastra harus menghibur, bermanfaat, atau bahkan harus menggerakkan pembaca menjadi manusia yang lebih baik. Sayangnya efek 
buruk dari kemapanan struktur ini melahirkan stagnasi.

Haryatmoko (2016, hal. 7) menyebutkan bahwa kepastian berisiko menjadi kemapanan dan ke-mandheg-an sehingga menjadi halangan untuk berkembang. Paling bahaya apabila yang mapan dan mandheg itu berhubungan dengan pemikiran. Di sini, kepastian bisa menjadi kebenaran yang tak mau diganggu gugat dan dogmatis. Tak sulit mencari bukti dalam sejarah bahwa kepastian pun ternyata bisa menjadi rezim yang mempunyai kebenaran mutlak. Pascastrukturalis lahir sebagai upaya membongkar kepastian itu. Beberapa tokoh pascastrukturalis yang pokok pemikirannya populer adalah Paul Ricoeur, Michael Foulcault, Jacues Derrida, Jean Baudrillard, dan Gilles Deleuze.

Foucault mengemukakan bahwa melalui wacanalah, kehendak untuk mengetahui terumus dalam pengetahuan. Bahasa menjadi alat untuk mengartikulasikan kekuasaan pada saat kekuasaan harus mengambil bentuk pengetahuan karena ilmu-ilmu terumus dalam bentuk pernyataan-pernyataan. Kekuasaan-pengetahuan terkonsentrasi di dalam kebenaran pernyataan-pernyataan ilmiah (Haryatmoko, 2016, hal. 17). Dari pernyataan tersebut dapat disimpulkan ada pihak yang memegang kuasa terhadap wacana.

Jika pandangan Foucault tersebut diimplementasikan pada kajian struktur karya sastra, maka secara ilmiah ada kriteria yang mengategorikan suatu buku sebagai novel atau buku tersebut adalah buku ilmiah. Bahkan lahir pula kriteria keilmuan yang membatasi ciri-ciri genre karya sastra ke dalam tiga kelompok, yaitu fiksi/prosa, puisi dan naskah drama. Beberapa sastrawan mencoba mendekonstruksi pembagian genre ini, misalnya dengan menghasilkan puisi yang prosais, prosa yang puitis, bahkan puisi esai. Para sastrawan pascastrukturalis ini mencoba melawan kekuasaan kelompok strukturalis. Dalam level analisis dan kritik sastra, perlawanan ini bahkan melahirkan teori interdisipliner antara ilmu sastra dan ilmu-ilmu lain.

Berbeda dengan Foucault yang memfokuskan pandangan pada kritik terhadap kekuasaan, Derrida (dalam Hayatmoko, 2016, hal. 133) mencoba membongkar rezim kepastian melalui dekonstruksi. Ketika penafsiran harus mengikuti aturan baku yang dijaga dan diawasi otoritas, dekonstruksi datang membongkar dan membuat resah otoritas itu. Dia menganggap bahwa sesuatu yang terstruktur dianggap setia dan seakan satu-satunya pembawa pesan teks yang paling benar. Dekonstruksi Derrida adalah upaya mengguncang, memindah, membongkar, mempertanyakan dan menghancurkan kemapanan struktur teks yang sudah ada sebelumnya.

Pandangan pascastrukturalis yang juga menarik dan relevan dengan penelitian ini adalah pandangan Jean Baudrillard mengenai postmodernisme. Baudrillard (dalam Haryatmoko, 2016, hal. 63-64) menyatakan bahwa sistem posmodern berangkat dari kepentingan masyarakat konsumerisme, manipulasi tanda, dan hiperealitas. Motivasi konsumsi barang mengacu pada slogan "Keindahan suasana ruang adalah syarat pertama kebahagiaan hidup". Jadi, makna keindahan dan dinamisme komersial menentukan warna konsumsi. Tanpa disadari berlangsunglah manipulasi tanda.

Pernyataan Baudrillard tersebut menegaskan konsep dan standar keindahan terbentuk dari konvensi yang mapan dalam struktur yang diterima oleh semua orang. Bahkan keindahan dianggap menjadi syarat pertama kebahagiaan hidup. Muara dari konsepsi ini adalah konsumerisme. Manusia rela mengeluarkan uang untuk membeli keindahan sebagai prasyarat kehidupan yang bahagia. Keindahan berharga mahal, demikianlah ciri masyarakat 
konsumerisme. Maka muncullah kelompok masyarakat termasuk sastrawan yang mencoba menolak konsepsi ini. Salah satunya dengan menghasilkan karya yang mendobrak standar keindahan tersebut.

\section{B. METODE}

Metode penelitian yang digunakan adalah deskriptif kualitatif dengan jenis penelitian kajian pustaka. Metode ini adalah metode paling tepat digunakan dalam penelitian bidang kajian humaniora, khususnya meneliti karya sastra. Objek kajian penelitian adalah novel Kiat Sukses Hancur Lebur karya Martin Suryajaya. Pengumpulan data dilakukan melalui kajian studi pustaka dan teknik yang digunakan adalah teknik baca dan catat. Teori yang digunakan untuk menganalisis novel tersebut adalah teori stilistika dengan langkah kerja menemukan penyimpanganpenyimpangan struktur dalam novel baik pada tataran leksikal, gramatikal, paragraf, dan wacana untuk menemukan stile khas pengarang yang membedakan dengan stile pengarang lain.

Proses penelitian meliputi tahap persiapan, pengumpulan data, pengolahan data hingga penyusunan laporan. Pola analisis yang dipilih sesuai dengan tipe penelitian kualitatif pada umumnya, yaitu data yang telah dikumpulkan akan dianalisis untuk mendapatkan hasil analisis awal. Data hasil analisis awal tersebut kemudian diinterpretasikan untuk pada akhirnya dapat ditarik hasil penelitian, simpulan dan saran.

\section{PEMBAHASAN}

Kiat Sukses Hancur Lebur adalah novel yang bercerita mengenai proses terbitnya buku karangan seorang tokoh fiktif bernama Thomas Tembong. Alur waktu pada novel ini digambarkan maju mundur sehingga diperlukan kecermatan pembaca untuk memahami plot yang digambarkan. Namun secara umum, novel ini berisi proses terbitnya buku karangan Thomas Tembong dari perspektif tokoh fiktif bernama Andi Lukito (editor dari buku tersebut). Setelah membaca novel ini dapat disimpulkan bahwa sebagian besar isi novel ini adalah merupakan isi dari buku yang diterbitkan oleh tokoh Thomas Tembong tersebut. Isi bukunya sesuai dengan judul, yaitu Kiat Sukses Hancur Lebur .

Novel ini dibuka dengan fragmen yang diberi judul "Catatan Editor" sejumlah 5 halaman dari halaman 9-13. Dikisahkan bahwa penulis bagian "Catatan Editor" tersebut adalah tokoh bernama Andi Lukito. Pusat penceritaan digambarkan dari sudut pandang tokoh tersebut. Pada bagian ini juga dimunculkan deskripsi penggambaran latar secara eksplisit namun tidak runut sehingga untuk dapat menyimpulkan urutan waktu harus dilakukan pembacaan ulang dan pencatatan. Latar waktu dalam novel ini adalah masa depan dengan runutan waktu yang telah diolah dari data fakta cerita sebagai berikut.

\section{Tabel 1. Runutan Waktu dalam Novel}

\begin{tabular}{cl}
\hline Tahun & \multicolumn{1}{c}{ Deskripsi } \\
\hline 2013 & Pada tahun 2013 penulis naskah novel ini bernama Anto Labil bertemu dengan sahabatnya \\
& bernama Thomas Tembong. Anto Labil lantas menitipkan naskah novel karangannya \\
& kepada Thomas Tembong untuk dibaca dan diberikan masukan. Judul awal yang dipilih oleh \\
& Anto Labil adalah Kitab Sastra Kerakyatan. \\
& Enam tahun kemudian, yaitu tahun 2019, Thomas Tembong memberikan naskah tersebut \\
& kepada muridnya dalam bidang ilmu kesusastraan yaitu tokoh bernama Andi Lukito untuk \\
& diterbitkan. Judul naskah berubah menjadi Kiat Sukses Hancur Lebur Menurut Anto Labil, S.Fil. \\
& Dikarenakan kesibukan tokoh Anto Labil, novel tersebut baru terbit dua belas tahun \\
& kemudian, tepatnya pada 25 April 2025.
\end{tabular}


Selain penggambaran latar waktu, penggambaran latar tempat dan tokoh juga dilakukan secara eksplisit. Diceritakan bahwa Thomas Tembong adalah satu dari sekelompok pemuda yang aktif pada organisasi persekutuan sastra radikal dekade 90 -an di Semarang. Tahun 1993 mereka bergabung dalam Jaringan Kerja Kebudayaan Rakyat (JAKER) yang mencoba menghidupkan kembali LEKRA dan menggiatkan perlawanan terhadap humanisme universal. Pada tahun 1996-1999, sekawanan itu aktif turun ke jalan berkenaan dengan aktivitas politik prodemokrasi khususnya PRD. Penggambaran latar tempat secara eksplisit dapat dilihat pada kutipan berikut.

"Guru saya menceritakan sebagian dari "petualangan sastrawi" mereka. Salah seorang dari mereka terlibat baku hantam dengan dosen sastra Undip yang sinis terhadap gerakan sastra kerakyatan dalam suatu sarasehan sastra di Taman Budaya Raden Saleh, Semarang. Salah seorang yang lain mengambil alih toa Masjid Kauman seberang Pasar Johar untuk membacakan puisi-puisi anti-Suharto. Kenakalan semacam itu ternyata mereka bawa juga ke Jakarta. Di tengah acara diskusi kritik sastra posmo yang diselenggarakan para begawan kesusastraan tanah air di Teater Orang Utan, salah seorang dari mereka berteriak "Copet! Aku kecopetan!" sehingga para peserta menjadi panik, memeriksa kantong masing-masing, saling mencurigai dan acara pun terpaksa dihentikan” (Suryajaya, 2016, hal. 10-11).

Dari paragraf tersebut dapat dilihat bahwa sebagian latar tempat dan sosial budaya yang muncul dapat ditemukan di dunia nyata, sedang sebagian yang lain adalah penyimpangan berbentuk parodi latar faktual ke fiksional. Latar tempat yang dapat ditemukan di kehidupan nyata di antaranya: Undip, Semarang, Masjid Kauman, Pasar Johar, serta latar sosial budaya meliputi: JAKER, LEKRA, PRD dan pergerakan tahun 1996-1999 adalah benar terjadi di kehidupan nyata. Namun kemunculan "Teater Otang Utan di Jakarta" adalah bentuk parodi yang dapat diasosiasikan dengan Teater Utan Kayu di Jakarta. Selain itu, penggambaran mengenai tokoh Anto Labil sebagai pengarang Kiat Sukses Hancur Lebur juga didominasi dengan penyimpangan dalam bentuk parodi seperti terlihat pada kutipan berikut.

\footnotetext{
"Menurut informasi yang bisa saya kumpulkan dari keterangan guru saya, Anto Labil dilahirkan di Semarang, Juni 1971. Ia lulus sebagai sarjana filsafat setelah merampungkan studinya di Sekolah Tinggi Filsafat Duryudana, Jakarta. Ia sempat mengajar kelas MKDU (Mata Kuliah Dasar Umum) Logika di UNIKA Dursusana dan Universitas Multimedia Pancakarsa. Itu berjalan selama tiga tahun, kalau saya tidak keliru, sebelum akhirnya ia pulang ke Semarang sebagai pemuda pengangguran dan bergabung dengan ketujuh pendekar" (Suryajaya, 2016, hal. 11).
}

Dapat dilihat bahwa pengarang sengaja memarodikan latar tempat. Sekolah Tinggi Filsafat Duryudana adalah bentuk parodi dari Sekolah Tinggi Filsafat Driyarkara, UNIKA Dursusana adalah parodi dari UNIKA Atmajaya. Sedang Universitas Multimedia Pancakarsa merupakan parodi dari beberapa kampus swasta dengan bidang keilmuan multimedia yang banyak ditemukan di Jakarta.

Selain temuan-temuan penyimpangan yang telah disebutkan sebelumnya, keanehan bentuk novel ini sebetulnya telah ditegaskan oleh pengarang melalui sudut pandang tokoh Andi Lukito dalam paragraf berikut.

"Saya sendiri mulanya bertanya-tanya apakah karya ini dimaksudkan sebagai suatu buku manual ataukah sebagai karya sastra, mengingat temanya berkisar pada tips-tips praktis yang dibumbui dongeng-dongeng kecil di sana sini dan dituliskan dengan gaya 
bahasa seorang penyair pemabuk yang hampir pingsan. Thomas Tembong mengatakan bahwa Anto meniatkan ini sebagai "novel" atau paling tidak "semacam novel". Saya tahu predikat itu agak problematis bagi kalangan kritikus yang lebih konservatif. Setidaknya, di sini bisa dikatakan secara relatif aman bahwa buku ini sebuah karya fiksi” (Suryajaya, 2016, hal. 12-13).

Dapat dilihat bahwa melalui tokoh Andi Lukito, pengarang ingin menyampaikan keragu-raguannya terhadap bentuk novel ini. Apakah ini buku panduan atau novel, meskipun keraguan ini disampaikan melalui gaya kelakar dan nada kocak. Penegasan bahwa penetapan bentuk buku ini sebagai novel agak problematik bagi kalangan kritikus konservatif juga menjadi penegas bahwa Suryajaya memiliki misi menawarkan kebaruan bentuk yang kontroversial. Secara konvensi, novel terdiri atas struktur narasi cerita yang dapat diterima. Namun Kiat Sukeses Hancur Lebur menawarkan loncatan bentuk dan logika yang melewati batas ambang toleransi konvensi.

Pada fragmen "Catatan Editor", alur dan tokoh masih memenuhi kriteria struktur novel. Meskipun ditemukan penyimpangan-penyimpangan dalam bentuk parodi serta gaya penceritaan yang sengaja dibuat berputar-putar, namun secara umum bentuk penceritaan terbaca normal dengan tokoh Andi Lukito sebagai narator cerita dengan sudut pandang akuan. Setelah mulai membaca novel, pembaca akan dibingungkan oleh strukturnya yang menyimpang dari kaidah novel pada umumnya. Susunan fragmen yang ditampilkan justru menyerupai pembagian bab buku panduan (non fiksi). Isi novel ini terdiri atas fragmen Catatan Editor, Bab I-VIII dan Daftar Pustaka. Berikut kutipan Bab III novel ini.

Bab III Dasar-Dasar Akuntansi Avant-Garde 1. Prolegomena bagi Akuntansi Avant-Garde 2. Akuntansi sebagai Jada Jual-Beli Tabel Bekas
3. Mendalami Inti Akuntansi Tanpa Penyedap Rasa

4. Avant-Gardisme pada Masa Purbakala (Suryajaya, 2016, hal. 5-6).

Berdasarkan pembagian Bab dan Subbab, dapat disimpulkan bahwa novel Kiat Sukses Hancur Lebur sengaja melakukan pelanggaran terhadap kohesi dan koherensi plot cerita. Ditemukan penyimpangan-penyimpangan yang disengaja untuk melahirkan efek ketegangan dan membingungkan pembaca. Adapun bentuk-bentuk penyimpangan akan dijelaskan secara rinci sebagai berikut.

\section{Penyimpangan Leksikal, Gramatikal dan Paragraf}

Penyimpangan kata pertama yang muncul dan cukup menyita perhatian adalah diksi pertama pada judul, yaitu kiat. Mengawali judul dengan kata kiat tentunya disengajakan untuk tujuan menyimpangkan konvensi sastra secara umum. Dalam KBBI, kiat artinya taktik, seni atau cara melakukan sesuatu. Buku yang diawali dengan kata kiat biasanya adalah buku panduan untuk melakukan atau mencapai sesuatu. Terlebih kiat yang ditulis bukan kiat melakukan hal positif atau hal baik, namun justru kiat sukses menuju kehancuran (hancur lebur). Dari judul saja pembaca dihadapkan pada pernyataan bahwa buku ini ditujukan bagi mereka yang ingin sukses hancur lebur.

Secara umum jenis kata yang dipilih untuk membangun narasi novel ini sangat variatif berasal dari berbagai macam disiplin ilmu mulai dari istilah filsafat, ekonomi, manajemen, teknologi, kedokteran, kesehatan, keseharian, kehidupan masyarakat urban, dan lain sebagainya. Keberagaman ragam diksi dapat dilihat dari kemunculan kata-kata berikut: cebok, buta buruf, dan babi butan (Suryajaya, 2016, hal. 15); SIM, STNK, Departemen Penerangan, dan Orde Baru (Suryajaya, 2016, hal. 19); akuntansi dokar onlen; Teluk Benoa, cagar budaya Pecel 
Madiun, dan avant-garde (Suryajaya, 2016, hal. 57); serta rigurat, syubada, iman, korpri, surga, kurma, dan Dewa Siwa (Suryajaya, 2016, hal. 157).

Ditemukan juga penyimpangan bahasa yang menghasilkan gaya atau stile autentik berupa kemunculan kosakata dalam bahasa daerah yaitu bahasa Jawa, misalnya kata pagupon dara, lincak, dan amben (Suryajaya, 2016, hal. 44); ciblek, jembut, dan gorengan (Suryajaya, 2016, hal. 83); serta kosakata bahasa slang atau istilah asing, di antaranya berabe (Suryajaya, 2016, hal. 37) dan doorprize (Suryajaya, 2016, hal. 77). Sayangnya penulisan kosakata bahasa daerah tersebut tidak ditulis dalam cetak miring atau disertai catatan kaki sehingga pembaca yang tidak menguasai bahasa Jawa rentan dibuat kebingungan. Selain penyimpangan dalam bentuk pemunculan kosakata bahasa daerah, dimunculkan juga repetisi kata yang ditampilkan secara acak namun bentuknya sangat tidak lazim. Repetisi tersebut membentuk mantra yang tujuannya menimbulkan efek bunyi yang ritmis, namun suasana yang terbangun adalah chaos. Bentuk penyimpangan ini dapat dilihat dari kutipan berikut.

Jakarta adalah sedimentasi pecel lele yang terekam secara stratigrafis pada penampang trotoar seperti lapis-lapis bukit kerang prasejarah-kjokkenmoddinger, mohenjodaro kuning, harappa-harappa palsu. Semua warga Jakarta makan pecel lele dan mengejan pecel lele, semuanya bicara pecel lele dan berdoa pecel lele-bekerja pecel lele, bermain pecel lele, bersetubuh pecel lele, bermimpi pecel lele, bepergian pecel lele, beristirahat pecel lele, berbasa-basi pecel lele, menonton sinetron pecel lele, mendengar musik pecel lele, menonton pertunjukan pecel lele, membaca novel pecel lele, mendengar musikalisasi pecel lele, bergaul pecel lele, berbudaya pecel lele, sekolah pecel lele, kuliah pecel lele, menikah pecel lele, melahirkan pecel lele, digaji pecel lele... (Suryajaya, 2016, hal. 147-148).
Repetisi kata pecel lele membentuk mantra yang terasa destruktif, menarik perhatian sekaligus mengganggu sehingga pembaca terkonsentrasi mempertanyakan sebetulnya "pesan" apa yang ingin disampaikan oleh pengarang. Repetisi juga dimunculkan untuk membangun nuansa sarkasme, yaitu kritik terhadap kesakralan undang-undang sebagai payung normatif suatu negara, serta sarkasme terhadap CPNS dan PNS. Bentuk sarkasme tersebut dapat dilihat pada paragraf berikut,

Tes Waralaba Kebangsaan adalah porsi ujian paling pelik dan berbelit-belit dari seluruh paket uji emisi CPNS 021-995-5162. Di dalamnya diujikan beberapa perkara mendasar terkait ontologi PNS. Salah satunya adalah tentang "Syarat kemungkinan" atau conditio sine qua non keberadaan PNS sebagai sebuah sistem filateli berjamaah. Acuannya adalah pada Undang-Undang Nomor 8 Tahun 1974 yang kemudian direvisi melalui Undang-Undang Nomor 43 Tahun 1999. UU dari tahun 1974 itu bunyinya begini:

"Cuittt... kresek-kresek.. mengingatken.. trilililit... maka dari itu... kruk-krukkruk.. becak saudara... brek-krekngiing... Achtung! Achtung! Kriiikkk... jebol-jebol-jebol... kak-krrararak... sutradara palsu... shshshshs... seturut instruksi Bapak Presiden... krekkrkrk... (Suryajaya, 2016, hal. 120).

Dari paragraf di atas juga dapat ditemukan manipulasi bunyi yang tidak membentuk kata dan tidak memiliki arti, namun memperkuat nuansa kekacauan. Manipulasi bunyi ini ditemukan secara acak menyebar dari awal hingga akhir novel yang mewarnai narasi dan dialog yang ada pada novel Kiat Sukses Hancur Lebur ini. Secara umum susunan kalimat juga dibuat tidak kohesi dan tidak koheren yang mengganggu logika saat dibaca, misal pada kalimat berikut: "Nah, kalau ini, Anda mesti mencolokkan kuping Anda pada sistem suara lapas narkotika supaya dapat mencairkan partikel dubuk di punggung ayam kate" (Suryajaya, 2016, hal. $57)$. 
Terlepas dari kekacauan yang dimunculkan dari penyimpangan aspek leksikal, gramatikal dan paragraf, Martin Suryajaya menguasai kosakata yang beragam dan diksi yang sangat kaya. Kekuatan novel ini juga terletak pada kemampuan pengarang merangkai kata dengan baik. Kesengajaan bentuk penyimpangan terasa mengalir karena kepiawaian pengarang merangkai kata dan menciptakan narasi cerita yang utuh. Pembaca bahkan sangat mungkin berkenalan dengan kosakata baru saat membaca novel ini.

\section{Penyimpangan Wacana}

Selain dalam tataran bahasa, ditemukan juga penyimpangan dalam tataran wacana atau diskursus sebagai bentuk kritik sosial yang berhasil terbangun dengan intens. Kritik tersebut disampaikan dengan gaya parodi melalui sarkasme yang terasa kocak sehingga suasana serius namun santai mampu dibangun dengan baik. Diskursus yang ingin ditampilkan oleh pengarang terbagi ke dalam 8 topik besar yang direpresentasikan ke dalam 8 bab. Sebagian wacana disampaikan melalui simbol yang beberapa di antaranya terasa sangat janggal. Berikut adalah data dan sajian hasil analisisnya.

\section{Tabel 2. Penyimpangan Wacana dalam Novel}

\begin{tabular}{|c|c|c|}
\hline No & Wacana & Bentuk Penyimpangan \& Tafsir Maknanya \\
\hline 1 & $\begin{array}{l}\text { Olok-olokan terhadap } \\
\text { "kesuksesan" sebagai } \\
\text { penegasan adanya kelas } \\
\text { sosial: sebab jika ada yang } \\
\text { sukses, maka tentu ada yang } \\
\text { gagal dan tersingkirkan. }\end{array}$ & $\begin{array}{l}\text { Bab ini terdiri atas } 2 \text { subbab dan dibuka dengan narasi penjelasan } \\
\text { hubungan "cebok" dengan kiat hidup sukses masa kini. Bab ini } \\
\text { menyebutkan pembaca buku ini adalah orang yang beruntung } \\
\text { mempelajari ilmu sukses. Ditampilkan paradoks: Ibukota/Jakarta } \\
\text { dan Papua dalam hal buta huruf dan kegemaran membaca novel. } \\
\text { Penyimpangan juga ditampilkan dengan pernyataan bahwa buku } \\
\text { kiat terdiri atas } 764.129 \text { Bab, namun sebagian belum sempat } \\
\text { dituliskan. Isu pertentangan kelas terasa melalui sarkasme diksi, } \\
\text { misal: nonrealis, pos-Marxis, serta pada kalimat penutup, "Panjang } \\
\text { umur perjuangan kelas! Panjang umur revolusi buah naga!" }\end{array}$ \\
\hline 2 & $\begin{array}{l}\text { Obsesi terhadap kiat sukses } \\
\text { manajemen bisnis sebagai } \\
\text { pengejawantahan sistem } \\
\text { kapitalistik. Paradoks "ilmu } \\
\text { manajemen bisnis" dan } \\
\text { "filsafat". }\end{array}$ & $\begin{array}{l}\text { Bab ini terdiri atas } 5 \text { subbab. Penyimpangan jelas terlihat dari } \\
\text { penjelasan istilah "manajemen bisnis" yang disebut berasal dari } \\
\text { bahasa Yunani yang berarti "cinta akan kebijaksanaan" (2016, hal. } \\
\text { 27). Pendefinisian tersebut adalah sindiran keras/sarkasme } \\
\text { terhadap ilmu manajemen yang digemari namun didefinisikan } \\
\text { dengan pengertian "filsafat". Pada bab ini juga dikutip pendapat } \\
\text { nama- nama tokoh filsuf besar dunia yang dilabeli sebagai } \\
\text { mahaguru bisnis, yaitu Immanuel Kant. Bab ini ditutup dengan } \\
\text { pertanyaan retoris mengenai apa gunanya mempelajari kiat ini, } \\
\text { serta pernyataan bahwa semangat manajemen sejati adalah } \\
\text { semangat "cinta akan kebijaksanaan", semangat "ketakjuban" akan } \\
\text { hal-hal yang mendatangkan uang (2016, hal. 47). }\end{array}$ \\
\hline 3 & $\begin{array}{l}\text { Pengejawantahan sistem } \\
\text { kapitalistik selanjutnya } \\
\text { adalah melalui ilmu } \\
\text { akuntansi yang didefinisikan } \\
\text { sebagai "menumpuk". } \\
\text { Kritik keras terhadap sistem } \\
\text { kapitalistik yang hanya } \\
\text { mementingkan aspek } \\
\text { untung-rugi. }\end{array}$ & $\begin{array}{l}\text { Bab ini terdiri atas } 4 \text { subbab. Selain membahas mengenai konsep } \\
\text { akuntansi, disebutkan juga beberapa nama yang identik dengan } \\
\text { ideologi komunisme namun dalam bentuk parodi, yaitu Bujang } \\
\text { Hitler, Friedrich Nari. Disebutkan juga nama politisi Indonesia } \\
\text { Setya Novanto melalui gaya kelakar yang satire (2016, hal. 53). } \\
\text { Menariknya, penjelasan mengenai ilmu akuntansi sebagai ilmu } \\
\text { "menumpuk" (kekayaan) disandingkan dengan avant-garde yang } \\
\text { banyak memunculkan diskursus mengenai isu-isu postmo- } \\
\text { dernisme. Gaha hiperbolis yang merepresentasikan kritik terhadap } \\
\text { eksploitasi alam dimunculkan pada penggambaran Telok Benoa } \\
\text { tahun } 2060 \text { di mana pada masa itu pecel Madiun menjelma } \\
\text { menjadi cagar budaya (2016, hal. 57). }\end{array}$ \\
\hline
\end{tabular}


$4 \quad$ Keterpukauan manusia terhadap kemajuan teknologi digital (komputer) dan keharusan menguasai keilmuannya apabila ingin menjadi manusia sukses.

$5 \quad$ Berisi lelucon mengenai eksklusivitas profesi Pegawai Negeri Sipil (PNS).

6 Ternak lele adalah solusi bagi mereka yang termarginalkan oleh sistem yang kapitalistik

7 Apartemen identik dengan kehidupan masyarakat urban, kepadatan penduduk, sempitnya lahan dan mahalnya harga rumah (kritik terhadap postmodernisme)

Pada bagian ini ditekankan mengenai identitas manusia dengan "baju" sebagai simbolnya. Identitas yang dimaksud secara ironi ditentukan melalui selembar ijazah.
Bab ini terdiri atas 4 subbab dan banyak menampilkan sindiran sarkasme terhadap keterpesonaan manusia terhadap kemajuan teknologi digital. Hal ini dapat dilihat pada kutipan berikut, " $D i$ masa depan, sejarah pemrograman komputer akan ditulis oleh para pemuda desa buta huruf yang gemar bersembahyang dalam botol-botol anggur kolesom Cap Orang Tua Murid' (2016, hal. 76). Pengarang bahkan menampilkan lelucon dengan membagi jenis komputer menjadi 4 macam, yaitu komputer sayur, komputer sapu, komputer isi ulang dan komputer kuping.

Bab ini terdiri atas 5 subbab. Disebutkan dalam novel bahwa solusi paling ideal untuk menghadapi permasalahan hidup adalah dengan menjadi PNS, "Ibarat kata, status PNS itu kunci pembuka pintu surga" (2016, hal. 103). Pada bab ini banyak dimunculkan wacana yang menyindir dan mengritik hegemoni pemerintahan Orde Baru dan propaganda mereka selama 32 tahun memimpin Indonesia.

Bab ini terdiri atas 4 subbab. Kemunculan "lele" terasa menyimpang dan mengganggu. Lele adalah analogi keputusasaan. Dimunculkan tokoh Mudrikah yang berpikir tentang kengerian maut, kekejaman manusia, penghancuran alam semesta dan ikan lele putih yang melahap semuanya. Isu tentang kegagalan dipertegas dengan kalimat penutup Bab, "Jangan Jual Ginjalmu" (2016, hal. 159).

Bab ini terdiri atas 4 subbab. Dijelaskan yang dimaksud apartemen dalam bab ini adalah, "Yang penulis maksud dengan apartemen mencakup baik apartemen per se (apartemen betulan sesuai namanya), apartemen accidens (apartemen sebagai eufemisme dari rusun ambrol), maupun apartemen per diem (apartemen gelandangan)... Apartemen ada banyak, mulai apartemen fasis, apartemen antifasis sampai apartemen bulgur dan apartemen dengkuP' (2016, hal. 162). Pada bab ini juga dibahas mengenai korelasi antara apartemen dengan bunuh diri sebagai pengejawantahan dari keputusasaan menghadapi kegagalan dalam hidup.

Bab ini terdiri atas 4 subbab. Dimunculkan tokoh bernama Dudung, seorang sarjana biologi dari universitas terkenal yang memutuskan membuka warung bubur kajang hijau. Pada suatu hari, Dadan menusukkan garpu pada seorang pemuda yang membeli bubur kacang hijau di kedainya. Secara sarkastis ditegaskan bahwa manusia tidak lebih dari selembar ijazah (identitasnya dilihat dari ijazah). Disebutkan ada 63 macam ilmu pengetahuan, di antaranya Ilmu pengetahuan alay, Ilmu pengetahuan sembelit dan Ilmu pengetahuan hancur-lebur. Ditampilkan pula kritik keras terhadap sistem pendidikan pada Subbab "Cara Mudah Menjadi Rektorat".
Selain pemaparan hasil analisis penyimpangan wacana berdasar pembagian jumlah bab di atas, ditemukan beberapa diskursus yang menyebar pada keseluruhan novel dari awal hingga akhir, yakni persoalan iman dan fanatisme terhadap agama, kritik terhadap ketimpangan kelas sosial, sinisme terhadap orde baru, pengenalan dasardasar pemikiran filsafat dengan menyebutkan istilah-istilah dari bidang keilmuan filsafat, serta banyaknya frekuensi kemunculan diksi yang berhubungan dengan pandangan dan tokoh-tokoh marxisme.

\section{Penyimpangan Alur Cerita}

Jika dicermati dengan saksama, maka narasi cerita hanya muncul pada bagian fragmen "Catatan Editor" dengan kemunculan tokoh-tokoh serta komponen latar yang diceritakan secara 
lengkap dan rinci. Narasi utamanya adalah: terbitnya buku yang ditulis oleh tokoh Anto Labil. Sedangkan Bab 1 hingga bagian Daftar Pustaka hanyalah bagian dari isi buku yang ditulis oleh Anto Labil. Tokoh Anto Labil pun tidak pernah benar-benar hadir karena penceritaan ditampilkan dari sudut pandang tokoh Andi Lukito yaitu editor dari buku yang diterbitkan tersebut. Cerita juga diperumit dengan fakta bahwa tokoh Anto Labil belum pernah bertemu dengan tokoh Andi Lukito. Normalnya novel terbangun dengan plot yang panjang dan struktur cerita yang lengkap. Sedangkan plot cerita novel ini hanya sebatas satu fragmen, sisanya adalah subbagian dari fragmen tersebut.

\section{Gaya yang Dipengaruhi \\ Penyimpangan Struktur}

Normalnya, novel disusun oleh narasi yang berisi kata, frasa, kalimat, paragraf dan wacana. Bentuk baru muncul dengan menggabungkan narasi cerita fiksi dengan gambar yang disebut novel grafis. Namun novel berjudul Kiat Sukses Hancur Lebur karya Martin Suryajaya ini menawarkan alternatif unsur lain, yaitu: tabel, bagan, gambar, ilustrasi, catatan kaki, neraca, bahkan daftar pustaka yang seluruh sumber rujukan yang dicantumkan di dalamnya fiktif. Berikut adalah tabel frekuensi kemunculan unsur lain tersebut.

Tabel 3. Frekuensi Kemunculan Unsur Lain

\begin{tabular}{clcl}
\hline No & Struktur Menyimpang & Frekuensi & \multicolumn{1}{c}{ Halaman } \\
\hline 1 & Catatan Kaki & 29 & $27,28,29,30,34,35,36,37,51,52,78,106,116$, \\
& & & $142,143,144,149,150,156,162,163,164,165$, \\
& & & $166,179,189,191,192,198$ \\
2 & Bagan, Diagram \& Skema & 7 & $35,36,39,44,47,64,126$ \\
3 & Lukisan/Gambar & 1 & 43 \\
4 & Jenis Garis & 1 & 55 \\
5 & Gambar, Foto \& Screenshot & 10 & $56,57,79,80,81,82,89,90,96,97$ \\
6 & Tabel & 7 & $61,62,67,131,132,133,205$ \\
7 & Neraca & 3 & $65,66,71$ \\
8 & Rumus/Shortcut Komputer & 8 & $92,93,94,95,99,124,181,182$ \\
9 & Peta & 1 & 127 \\
10 & Daftar Pustaka & 44 & $213,214,215$ \\
\hline
\end{tabular}

Dari data tersebut dapat dilihat bentuk-bentuk tidak wajar yang dimunculkan dalam novel. Bagian akhir novel ditutup dengan Daftar Pustaka yang fiktif. Beberapa data pustaka adalah parodi dari beberapa tokoh yang dikenal dalam dunia nyata, misalnya: "Subagyo Sastrowardoyong. 1971. Bakat Alam dan Intel Orde Lama: Sebuah Persembahan Estetik. bagi Paduka Yang Mulia Subarto, majalah Caprisone, no. 10". Contoh lain data Daftar Pustaka yang menyita perhatian pembaca, misalnya: "Paracetamol, 1987. "On common substance", dalam The Hermetic and Alchemical Writings of
Paracetamol, Brillo." dan "Tuhan YME. 2004. Bagaimana Kata-kata Saya Berulangkali Disalahpahami, Bagaimana Saya Sibuke Menglarifikasi dan Bagaimana Saya Akbirnya Mengiklaskannya, Perebit Tuhan YME." (Suryajaya, 2016, hal. 214 -215).

\section{PENUTUP}

Berdasarkan hasil analisis, ditemukan banyak penyimpangan dalam novel Kiat Sukeses Hancur Lebur karya Martin Suryajaya. Penyimpangan ditemukan dalam level bentuk/struktur, leksikal, hingga wacana. Penyimpangan pada penyusunan unsur leksikal, gramatikal 
dan paragraf ditemukan pada pemilihan diksi yang sangat variatif namun terasa janggal; banyaknya penggunaan kata dari bahasa daerah dan bahasa slang, serta susunan kalimat dan paragraf yang gagal membentuk kohesi dan koherensi. Kegagalan ini adalah kesengajaan untuk membentuk stile kekacaubalauan. Selain itu ditemukan pula repetisi yang membentuk semacam mantra, namun diksi penyusunnya berasal dari kosakata yang identik dengan kehidupan kaum urban di era postmodernisme.

Penyampaian wacana dilakukan melalui simbol-simbol disertai suasana humor yang sarkastis dengan motif kritik sosial. Wacana yang disimpangkan dalam novel ini bertujuan menyampaikan kritik terhadap sistem kapitalis yang melahirkan kelas sosial dan ketimpangan ekonomi, sindiran terhadap hegemoni orde baru, dan diskursus mengenai isu-isu multikultural serta kehidupan kaum urban di era postmodernisme.

Penyimpangan struktur ditemukan pada plot atau alur narasi cerita yang hanya disebutkan pada fragmen "Catatan Editor”, sedangkan Bab 1 hingga Daftar Pustaka adalah isi dari buku yang diterbitkan oleh tokoh yang muncul pada fragmen "Catatan Editor" tersebut. Penyimpangan terakhir yang ditemukan adalah bentuk penyampaian teks novel yang bukan hanya menyampaikan cerita melalui narasi kata-kata, namun juga dalam bentuk lain yaitu catatan kaki, bagan, diagram, skema, lukisan, gambar, jenis garis, gambar, foto, tabel, neraca, rumus, peta dan daftar pustaka. Bentuk ini tidak lazim bagi novel karena menyerupai bentuk buku non fiksi.

Dari temuan penyimpanganpenyimpangan tersebut dapat disimpulkan bahwa Martin Suryajaya melalui Kiat Sukses Hancur Lebur sengaja menghasilkan karya dengan bentuk baru yang bertolak belakang dengan struktur formal novel pada umumnya. Novel ini menawarkan bentuk baru yang mengusik konvensi definisi novel yang sudah mapan. Novel ini bahkan mengobrakabrik standar keindahan dengan menawarkan bentuk absurditas melalui kejanggalan-kejanggalan di dalamnya. Indah tidak selalu tersusun dari keteraturan dan kemapanan struktur. Indah juga bisa terbentuk dari kesia-siaan, sesuai dengan prinsip absurditas. Karya ini juga merupakan representasi nyata kerja sastrawan pascastrukturalis yang merasa jenuh dengan model novel yang konvensional. Sastra tidak harus indah dan berguna. Sastra juga bisa jadi sebuah kesia-siaan. Namun justru dari kesia-siaan itu lahir perenungan yang mampu mengubah pemikiran pembacanya.

Keindahan yang ingin ditampilkan oleh Suryajaya adalah bentuk keindahan melalui ketidakteraturan, hal-hal yang tidak masuk akal, tidak harmonis, mustahil dan sia-sia. Sayangnya pembaca dibuat kebingungan menangkap makna yang ingin disampaikan. Efek kebingungan yang muncul setelah membaca novel ini juga mengusik dan tidak menyenangkan bagi pembaca. Terlepas dari kekurangan tersebut, keunggulan novel ini adalah kepiawaian pengarang menampilkan diksi yang beragam serta multidimensional dan lintas bidang. Novel ini juga menawarkan kebaruan bentuk yang belum pernah ditawarkan oleh sastrawan lain. Menarik perhatian dan berhasil membongkar struktur novel pada umumnya. Martin Suryajawa melalui novel ini juga berhasil menegaskan gaya atau stile khas yang membedakannya dengan sastrawan lain, bahkan belum pernah ada sebelumnya.

\section{DAFTAR PUSTAKA}

Aminuddin. (1995). Stilistika Pengantar Memahami Bahasa dalam Karya Sastra. Semarang: IKIP Semarang Press.

Haryatmoko. (2016). Membongkar Rezim Kepastian Pemikiran Kritis Post- 
Strukturalis. Yogyakarta: Penerbit Kanisius.

Norris, C. (2006). Membongkar Teori Dekonstruksi Jaques Derrida. Yogyakarta: Ar Ruzz.

Nurgiyantoro, B. (2014). Stilistika. Yogyakarta: Gadjah Mada University Press.

Ratna, N. K. (2009). Stilistika Kajian Puitika Bahasa, Sastra, dan Budaya. Yogyakarta: Pustaka Pelajar.

Ratna, N. K. (2015). Teori, Metode, dan Teknik Penelitian Sastra dari Strukturalisme bingga Pascastrukturalisme Perspektif Wacana Naratif. Yogyakarta: Pustaka Pelajar.

Ryan, M. (2011). Teori Sastra Sebuah Pengantar Praktis. Yogyakarta: Jalasutra.

Satoto, S. (2012). Stilistika. Yogyakarta: Penerbit Ombak.
Semi, A. (2008). Stilistika Sastra. Padang: UNP Press.

Sudjiman, P. (1986). Kamus Istilah Sastra. Jakarta: Gramedia.

Suryajaya, M. (2016). Kiat Sukses Hancur Lebur. Jakarta: Penerbit Banana

Sutrisno, F. M. \& Verhaak, C. (1993). Estetika Filsafat Keindahan. Yogyakarta: Penerbit Kanisius.

Sutrisno, M. (2006). Oase Estetis Estetika dalam Kata dan Sketza. Yogyakarta: Penerbit Kanisius.

Teeuw, A. (1984). Sastra dan Ilmu Sastra: Pengantar Teori Sastra. Jakarta: Pustaka Jaya.

Wellek, R. \& Warren, A. (2016). Teori Kesusastraan. Jakarta: PT Gramedia Pustaka Utama. 